\title{
Optimalisasi Kinerja Simpang Bersinyal Kawasan Pertokoan Majene
}

\author{
Akbar Indrawan Saudi, ST., MT*1., Nur Fahri Tadjuddin, S.Pd., M.PMat ${ }^{2}$, Amalia Nurdin ST., MT. \\ 1. Teknik Sipil, Teknik, Universitas Sulawesi Barat, \\ 2. Pendidikan Matematika, Universitas Sulawesi Barat, \\ 3. Teknik Sipil, Teknik, Universitas Sulawesi Barat. \\ *e-mail: akbarindrawan@unsulbar.ac.id.
}

\begin{abstract}
The increase of traffic flow can have an impact on decreasing performance of intersection if no further preventive action is taken. The volume of traffic on the main roads in Kabupaten Majene has increased every year which has an impact on the performance of the intersections, especially those located in the shopping area of the city of Majene. The increase of that traffic flow is exacerbated by the presence of side barriers that occur around the intersection. The purpose of this study is analyzing the condition of existing signalized intersection and alternative treatments based on the 1997 Indonesian Road Capacity Manual. The problem that arises is the existence of queues and delays, so that data retrieval is required with a traffic survey, signal time survey, and the phase of the crossrod carried out for 12 hours of observation. The intersection performance analysis is done by finding the value of DS (degree of saturation), Queueing and Delay. The results of the study showed that the DS value in the exiting conditions the average for the intersection arm was 0.82 (east approach) and 0.81 (western approach). The queue that occurred was $104.33 \mathrm{~m}$ (north approach) and the total delay for the entire intersection was 51365.8 smp.det and for the delay 22.34 seconds /smp.
\end{abstract}

Keywords: The intersection performance, MKJI, Delay, Degree Of Saturation, Queueing, signalized intersection.

\begin{abstract}
Abstrak
Peningkatan arus lalu lintas berdampak pada penurunan kinerja pelayanan simpang jika tidak dilakukan tindakan preventif lebih lanjut. Volume lalu lintas di ruas jalan utama Kabupaten Majene mengalami peningkatan setiap tahunnya yang berdampak pada kinerja simpang khususnya yang berlokasi kawasan pertokoan kota Majene, peningkatan arus lalu lintas tersebut diperparah dengan adanya aktifitas hambatan samping yang terjadi disekitar simpang tersebut. Tujuan penelitian adalah menganalisis kondisi eksisting simpang bersinyal dan alternatif penanganan berdasarkan pedoman Manual Kapasitas Jalan Indonesia 1997. Permasalahan yang timbul terlihat dari timbulnya antrian dan tundaan yang terlihat, sehingga diperlukan pengambilan data dengan survey lalu lintas, survey waktu sinyal dan fase simpang yang dilakukan selama 12 jam pengamatan. Analisis kinerja simpang dilakukan dengan mencari nilai DS (degree of saturation), antrian (queueing) dan tundaan (delay). Hasil penelitian mendapatkan nilai DS pada kondisi eksiting rata-rata untuk lengan simpang adalah 0,82 (pendekat timur) dan 0,81 (pendekat barat). Antrian yang terjadi yaitu sepanjang $104.33 \mathrm{~m}$ (pendekat utara) serta tundaan total untuk keseluruhan simpang adalah 51365,8 smp.det dan untuk tundaan $22,34 \mathrm{detik} / \mathrm{smp}$.
\end{abstract}

Kata Kunci : Kinerja Simpang, MKJI, Tundaan, Degree Of Saturation, Antrian, Simpang Bersinyal. 


\section{Pendahuluan}

Kabupaten Majene merupakan salah satu kabupaten di Sulawesi Barat yang berperan sebagai pusat pendidikan dan pengajaran bagi kawasan di sekitarnya. Hal ini dapat dilihat dari berdirinya beberapa lembaga pendidikan, baik pendidikan menengah maupun pendidikan tinggi. Sampai saat ini, Kabupaten Majene merupakan satu-satunya kabupaten di wilayah Sulawesi Barat yang dihuni oleh institusi pendidikan tinggi negeri, satu hal yang tidak dimiliki oleh kabupaten lain di Sulawesi Barat. Ada dua institusi pendidikan tinggi negeri yang berlokasi di Kabupaten Majene, Universitas Sulawesi Barat dan Sekolah Tinggi Agama Islam Negeri (STAIN) Majene.

Sebagai pusat pendidikan di wilayah Sulawesi Barat, volume lalu lintas di ruas jalan utama Kabupaten Majene cukup besar, khususnya di kawasan kota. Hampir setiap hari terjadi kepadatan lalu lintas di beberapa simpang jalan, terutama di pagi dan sore hari dimana orang-orang memulai dan mengahkiri aktivitas sepanjang hari. Letak geografis Kabupaten Majene yang berada di jalur utama perlintasan Makassar-Mamuju turut memberi andil besarnya volume lalu lintas di daerah ini. Pertumbuhan serta perningkatan kepemilikan kendaraan pribadi tidak diimbangi dengan pertumbuhan supply yang dalam hal ini peningkatan ruas jalan dan peningkatan kemantapan pelayanannya.

Simpang bersinyal kawasan pertokoan Majene terletak di pusat perbelanjaan kota Majene yang merupakan bagian dari jalur Trans Sulawesi. Simpang bersinyal ini terdiri dari empat lengan yang mempertemukan empat ruas jalan, yaitu jalan Mayjen Aziz Bustam di Utara, jalan Tambaru di Selatan, Jalan Jendral Sudirman di Timur, dan jalan Gatot Subroto di Barat. Arah Timur-Barat merupakan jalur utama Majene-Mamuju dan arah Utara-Selatan merupakan jalur utama Pasar Sentral-Taman Kota. Karena lokasinya yang berada di pusat keramaian, baik dari arah Utara-Selatan ataupun Timur-Barat, volume lalu lintas di simpang bersinyal kawasan pertokoan Majene cukup besar mulai dari pagi hingga sore hari. Implikasi dengan adanya kawasan pertokoan di sekitar simpang tersebut menjadikan tingkat hambatan samping menjadi tinggi dan mempengaruhi pergerakan kendaraan di lengan simpang.

Permasalahan yang sering terjadi khususnya di lokasi simpang bersinyal adalah timbulnya antrian dan tundaan di setiap lengan simpang. Beberapa kendaraan bermotor terlihat menumpuk di salah satu lengan simpang hampir setiap hari, terlebih menjelang pagi dan sore hari atau yang disebut jam puncak. Tumpukan kendaraan ini mengakibatkan terjadinya kepadatan lalu lintas di sekitar kawasan pertokoan Majene. Berdasarkan hal tersebut, penelitian ini dianggap penting guna meningkatkan kinerja simpang bersinyal di kawasan pertokoan Majene. Keberadaan tugu pahlawan yang terletak pada salah satu lengan simpang semakin menambah permasalahan pergerakan kendaraan yang akan melalui simpang tersebut.

Tujuan dalam penelitian ini adalah mengkaji kinerja kondisi eksisting simpang bersinyal dengan parameter yang telah dijadikan standar dalam Manual Kapasitas Jalan Indonesia 1997 (MKJI 97') dan melakukan analisis lebih lanjut sehingga dapat menghasilkan solusi alternatif yang dapat dilakukan ataupun langkah antisipasi dalam hal meningkatkan kinerja pelayanan dari simpang tersebut. Hipotesis awal mengenai masalah yang terjadi adalah diperlukan adanya skenario perbaikan dalam rangka peningkatan kinerjanya yaitu dengan mengatur waktu sinyal dan perubahan fase simpang.

\section{Metode}

\section{A. Lokasi dan Waktu Penelitian}

Dengan pertimbangan permasalahan yang dijelaskan dalam pendahuluan sebelumnya, lokasi penelitian yang ditinjau dalam penelitian ini dilakukan di simpang bersinyal kawasan pertokoan Majene yang berada di Ling. Battayang, Kecamatan Banggae, Kabupaten Majene. Waktu Pelaksanaan penelitian ini dilaksanakan pada Kamis, 5 Maret 2020 yang merupakan hari kerja sehingga aktifitas kendaraan yang paling utama dapat diakomodir. Waktu survey yang menjadi kajian dalam pengambilan data dilakukan selama 12 jam dari pukul 06.00 sampai dengan 18.00 .

\section{B. Objek Penelitian}

Objek penelitian adalah volume lalu lintas yang bergerak di setiap lengan simpang bersinyal kawasan pertokoan Majene dan kinerja pelayanan simpang bersinyal tersebut.

\section{Teknik Pengumpulan Data}

1. Data volume lalu lintas, dilakukan dengan mencatat jumlah pergerakan kendaraan yang keluar masuk di masingmasing lengan simpang selama waktu pengamatan dengan klasifikasi kendaraan yang telah dijelaskan dalam Manual Kapasitas Jalan Indonesia 1997 dengan interval pencatatan selang waktu 15 menit. 
2. Data waktu sinyal dan fase simpang, dengan mencatat panjang waktu sinyal, yaitu jumlah waktu hijau, waktu kuning, dan waktu merah. Jumlah fase simpang di catat dimana pada waktu hijau kendaraan dibagian mana yang bergerak.

3. Data geometrik simpang, dilakukan dengan mengukur lengan simpang dengan menggunakan alat ukur atau roll meter sesuai dengan pedoman penghitungan kinerja simpang yang diatur dalam MKJI 1997.

4. Data Hambatan Samping, dikumpulkan dengan cara mencatat jumlah pergerakan, kendaraaan yang keluar masuk di sisi jalan, kendaraan parkir yang menggunakan badan jalan (on street), kendaraan yang bergerak lambat dan kendaraan tak bermotor. Seluruh jenis pergerakan tersebut dicatat selama waktu pengambilan data volume lalu lintas.

\section{Results}

Hasil pengukuran lapangan diperoleh data geometrik simpang kawasan pertokoan majene, tipe simpang dikategorikan 411 yaitu simpang dengan 4 lengan dan di setiap lengan baik pendekat jalan mayor maupun pendekat minor memiliki 1 lajur yang digunakan untuk berhenti maupun kedatangan kendaraan. Dapat dilihat pada gambar dibawah ini.

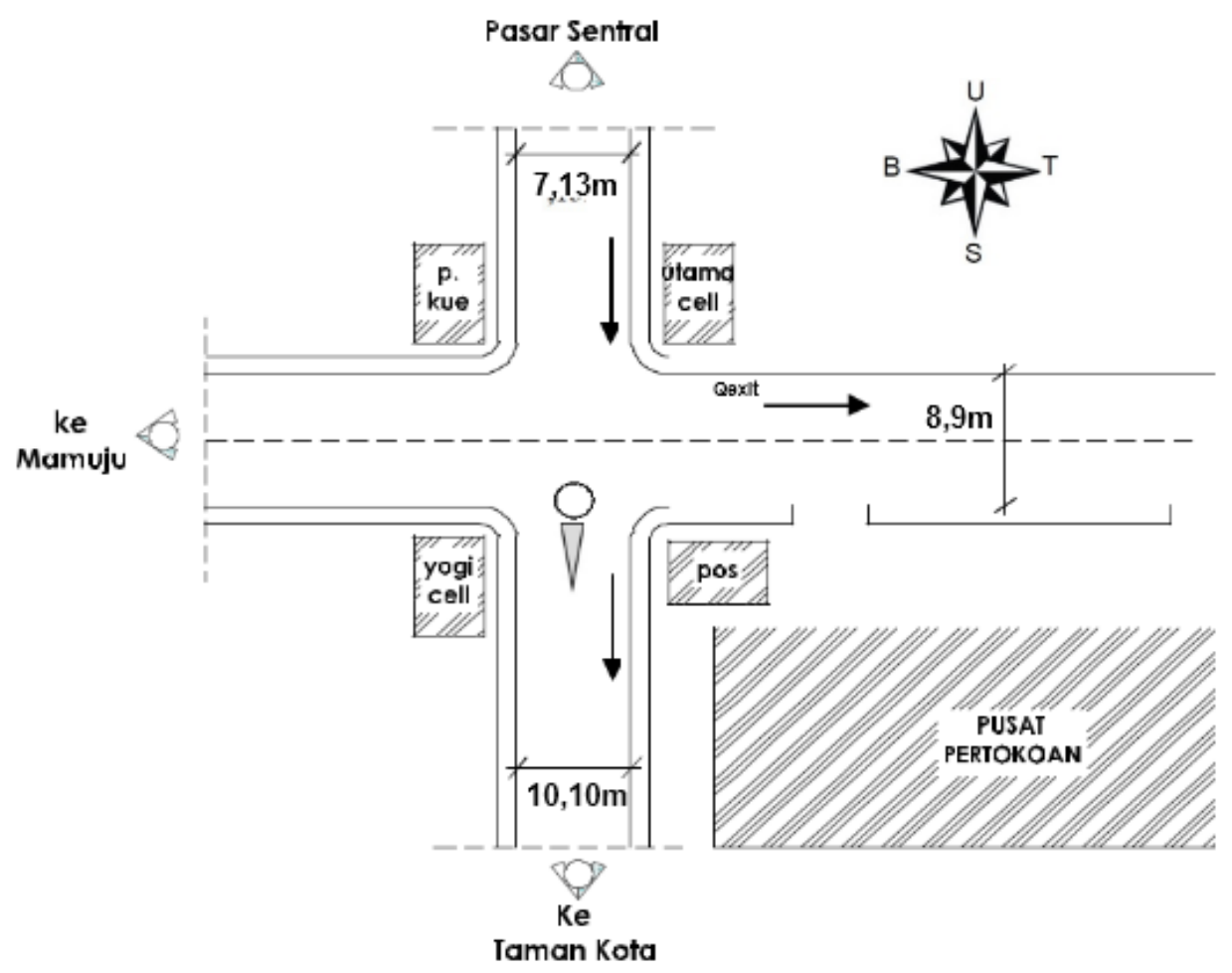

Gambar 1. Kondisi Geometrik Simpang Bersinyal Kawasan Pertokoan Majene

Lengan sisi timur dan barat yang masuk dalam kategori jalan mayor memiliki 2 lajur 2 arah dengan ukuran lebar yang dimiliki yaitu 8,9 meter. Lengan sisi utara dan selatan sebagai kategori jalan minor sama juga memiliki 2 lajur 2 arah dengan lebar 7,13 m untuk lengan utara serta 10,10 m untuk lebar pendekat arah selatan. Pada sisi lengan pendekat selatan terdapat monumen pahlawan mandar yang posisinya menjadi pertimbangan dalam perhitungan analisis kedepan. Dari hasil survei pengumpulan data diperoleh data proporsi kendaraan yang melalui simpang tersebut, dapat dilihat pada tabel yang berikut.

Tabel 1. Jumlah Kendaraan Bermotor Pada Simpang Bersinyal Pertokoan

\begin{tabular}{cccccc}
\hline Lengan/Pendekat & $\begin{array}{c}\text { Kendaraan } \\
\text { Ringan (LV) }\end{array}$ & $\begin{array}{c}\text { Kendaraan } \\
\text { Berat (HV) }\end{array}$ & $\begin{array}{c}\text { Kendaraan } \\
\text { Bermotor (MC) }\end{array}$ & $\begin{array}{c}\text { Kendaraan Tak } \\
\text { Bermotor (UM) }\end{array}$ & Total \\
\hline Barat & 2348 & 190 & 7320 & 803 & 10661 \\
\hline Timur & 2260 & 246 & 7221 & 724 & 10451 \\
\hline Utara & 2916 & 221 & 9387 & 614 & 13138 \\
\hline Selatan & 1053 & 3 & 1398 & 421 & 2875 \\
\hline
\end{tabular}

(sumber: Hasil Analisis, 2020) 
Dari proporsi kendaraan juga mengindikasikan bahwa kendaraan yang bergerak dari utara sangat dominan dengan total 13138 kendaraan dan pergerakan kendaraan yang paling rendah berasal dari lengan simpang sisi selatan dengan jumlah pergerakan 2875 kendaraan selama waktu pengambilan data. Untuk pergerakan kendaraan dari jalan mayor yaitu pergerakan lengan timur sebanyak 10451 kendaraan dan pergerakan lengan barat sebanyak 10661 kendaraan. Kendaraan tak bermotor yang melewati umumnya melewati simpang tersebut yaitu sepeda, becak, dan bendi yang masih menjadi alternatif pilihan transportasi masyarakat kabupaten Majene dalam melakukan aktifitas pemenuhan kebutuhannya seharihari.

\section{Proporsi Kendaraan Pendekat Barat}

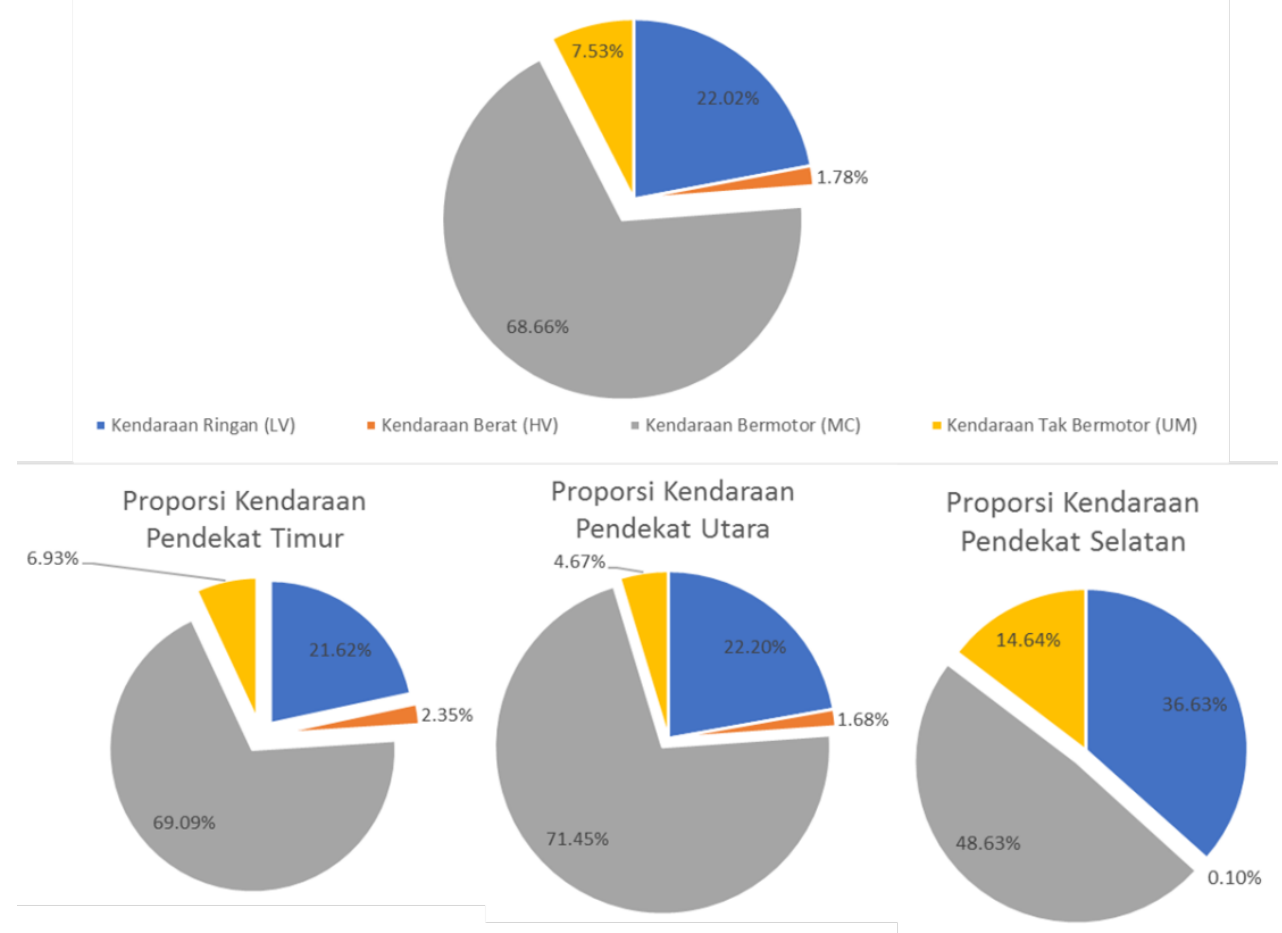

Gambar 2. Proporsi Kendaraan di Setiap Lengan Pendekat Simpang

Berdasarkan hasil kompilasi data survei yang telah dilakukan dari sumber lokasi pengamatan didapatkan bahwa dominasi kendaraan yang paling besar yaitu kendaraan bermotor (motorcycle), hasil ini mengindikasikan bahwa pertumbuhan kepemilikan motor dalam penggunaan sehari-hari masih menjadi pilihan yang utama dalam pergerakan masyarakat di Kabupaten Majene. Kendaraan Ringan (Light Vehicle) menempati posisi kedua dalam proporsi kendaraan yang bergerak melewati simpang tersebut, selanjutnya Kendaraan Tak Bermotor (Unmotorcycle) dan yang terakhir Kendaraan Berat (Heavy Vehicle) seperti, truk, bus yang melintasi ruas jalan utama yang terdapat di simpang.

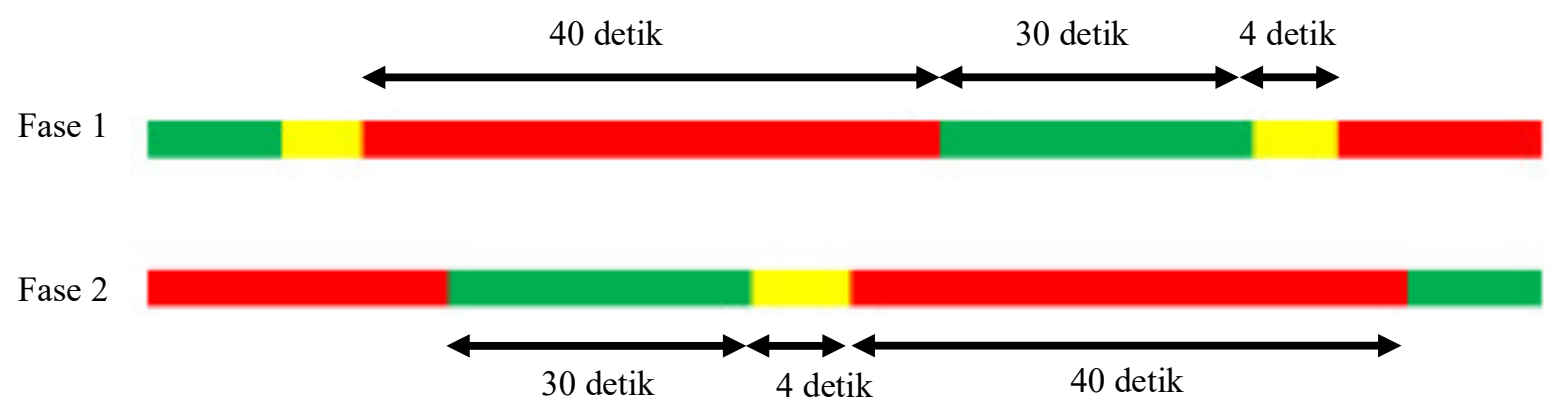

Gambar 3. Pengaturan Sinyal Simpang Dua Fase

Penggunaan lampu bersinyal pada simpang tujuannya adalah untuk memisahkan pergerakan yang mengalami kondisi terlawan dari pergerakan kendaraan yang datang dari arah berlawan dengan tujuan memimalkan terjadinya kecelakaan lalu lintas atau meningkatkan keselamatan lalu lintas. Dalam kasus penelitian ini terdapat 2 fase pergerakan. Fase pertama yaitu 
pergerakan lengan Barat dan Timur bergerak bersamaan pada waktu hijau dengan durasi 30 detik (second) selanjutnya berlanjut pada fase kedua dengan pergerakan lengan Utara dan Selatan yang berhenti sepanjang waktu merah dengan durasi 40 detik (second). Dengan melihat gambar diagram pengaturan sinyal diatas waktu siklus kedua fase memiliki nilai sama yaitu 74 detik (second).

Fluktuasi Kendaraan Arah Barat (kend/jam)

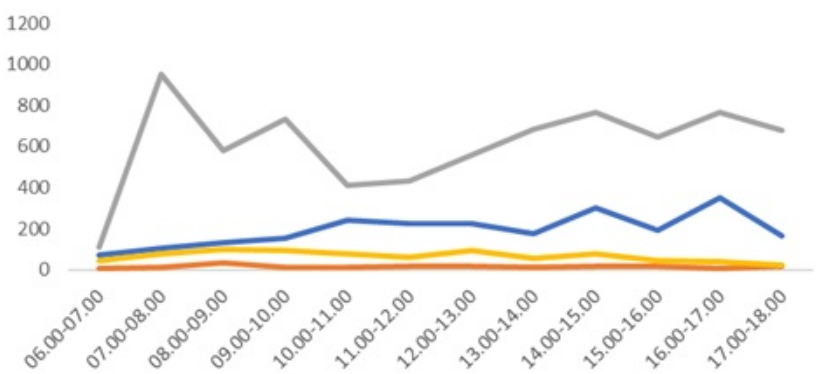

Fluktuasi Kendaraan Arah Utara (kend/jam)

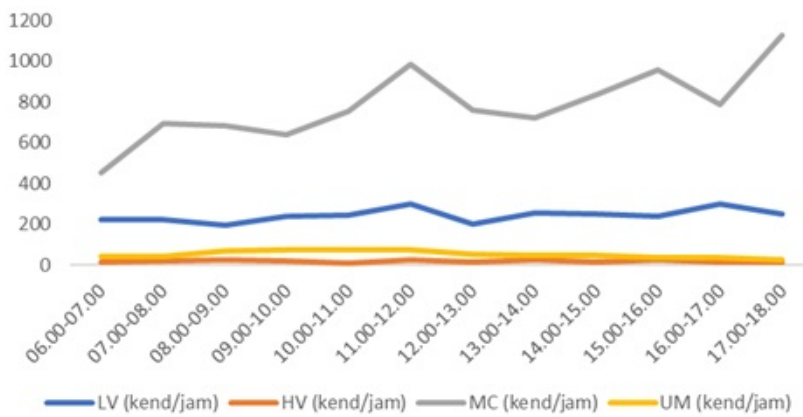

Fluktuasi Kendaraan Arah Timur (kend/jam)

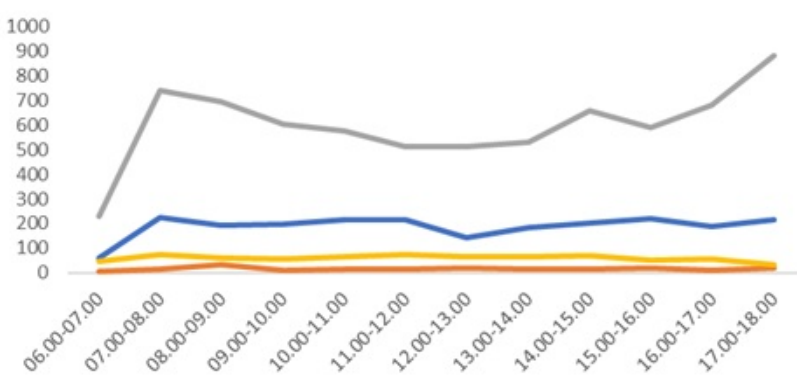

Fluktuasi Kendaraan Arah Selatan (kend/jam)

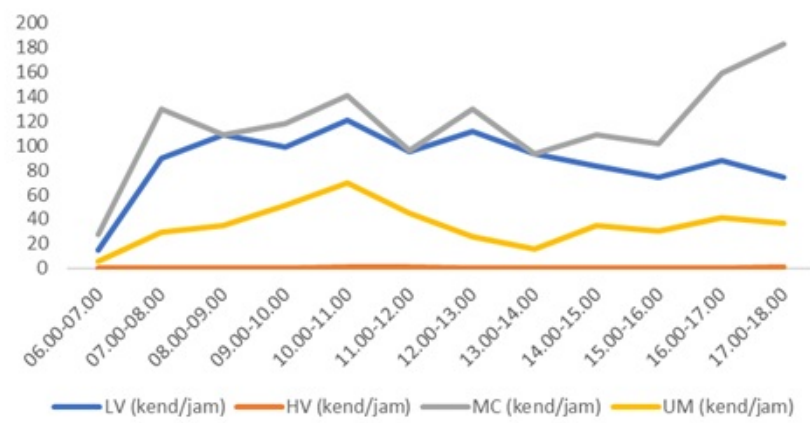

\section{Gambar 4. Fluktuasi Pergerakan Kendaraan Setiap Lengan Simpang}

Dari grafik fluktuasi lalu lintas diatas terlihat terdapat kondisi di waktu-waktu tertentu terjadi kenaikan signifikan yang biasa disebut jam puncak, dimana jumlah kendaraan lebih tinggi dibandingkan waktu-waktu yang lain sepanjang waktu pengamatan. Pada pendekat barat jumlah total kendaraan pada jam puncak sore sebesar 1166 kendaraan pada pukul 16.0017.00. Pada pendekat timur jumlah kendaraan yang menduduki jam puncak sebesar 1151 kendaraan yang berlangsung pada pukul 17.00-18.00. Jam puncak yang terjadi pada pendekat utara sebesar 1418 kendaraan yang terjadi pukul 17.00-18.00 dan pendekat selatan yang mempunyai nilai paling kecil sebesar 333 kendaraan di jam puncak siang pada pukul 10.0011.00 .

Tabel 2. Kinerja Simpang Bersinyal Pertokoan Kondisi Eksisting

\begin{tabular}{|c|c|c|c|c|c|c|c|c|c|}
\hline \multirow[b]{2}{*}{ Pendekat } & \multirow[b]{2}{*}{$\begin{array}{c}\text { Waktu } \\
\text { sinyal } \\
\text { (green } \\
\text { time) }\end{array}$} & \multirow[b]{2}{*}{ DS } & \multirow[b]{2}{*}{$\begin{array}{l}\text { Panjang } \\
\text { Antrian } \\
\text { (m) }\end{array}$} & \multirow[b]{2}{*}{$\begin{array}{c}\text { Rasio } \\
\text { Kendaraan } \\
\text { stop/smp }\end{array}$} & \multirow[b]{2}{*}{$\begin{array}{c}\text { Jumlah } \\
\text { Kendaraan } \\
\text { Terhenti } \\
\text { smp/jam }\end{array}$} & \multicolumn{4}{|c|}{ Tundaan } \\
\hline & & & & & & $\begin{array}{c}\text { Tundaan } \\
\text { lalu } \\
\text { lintas } \\
\text { rata-rata } \\
\text { det/smp }\end{array}$ & $\begin{array}{c}\text { Tundaan } \\
\text { geometrik } \\
\text { rata-rata } \\
\text { det/smp }\end{array}$ & $\begin{array}{c}\text { Tundaan } \\
\text { rata- } \\
\text { rata } \\
\text { det } / \text { smp } \\
D=\end{array}$ & $\begin{array}{c}\text { Tundaan } \\
\text { total } \\
\text { smp.det }\end{array}$ \\
\hline $\mathrm{U}$ & \multirow{2}{*}{30} & 0.76 & 104.33 & 0.81 & 586.44 & 17.87 & 3.71 & 21.58 & 15575.84 \\
\hline $\mathrm{S}$ & & 0.27 & 26.34 & 0.55 & 98.00 & 10.36 & 4.70 & 15.06 & 2690.49 \\
\hline $\mathrm{T}$ & \multirow{2}{*}{30} & 0.82 & 70.92 & 0.93 & 546.75 & 23.40 & 3.85 & 27.25 & 16078.28 \\
\hline B & & 0.81 & 77.03 & 0.90 & 600.00 & 21.81 & 3.65 & 25.46 & 17021.21 \\
\hline
\end{tabular}

(sumber: Hasil Analisis, 2020)

Berdasarkan hasil analisis simpang bersinyal paramater yang digunakan sesuai dengan petunjuk Manual Kapasitas Jalan Indonesia Tahun 1997 yaitu nilai DS (Degree of Saturation), Panjang Antrian, Jumlah Kendaraan Terhenti, Angka Henti 
dan Tundaan. Kondisi batasan yang diberlakukan dalam menilai kinerja simpang bersinyal dinyatakan dalam batasan yang mengunakan skala terukur yaitu nilai DS ditetapkan tidak boleh lebih dari 0,85. Melihat hasil analisis simpang kondisi eksisting bahwa terdapat lengan simpang yang melebihi ambang batas nilai DS yang ditetapkan dalam dokumen MKJI 1997 dan masuk dalam kategori jenuh yang dapat diindikasikan bahwa kapasitas simpang tidak mampu menampung kedatangan arus kendaraan.

Tabel 3. Kinerja Simpang Bersinyal Pertokoan Kondisi Perubahan Waktu Sinyal

\begin{tabular}{|c|c|c|c|c|c|c|c|c|c|}
\hline \multirow[b]{2}{*}{ Pendekat } & \multirow[b]{2}{*}{$\begin{array}{c}\text { Waktu } \\
\text { sinyal } \\
\text { (green } \\
\text { time) }\end{array}$} & \multirow[b]{2}{*}{ DS } & \multirow[b]{2}{*}{$\begin{array}{l}\text { Panjang } \\
\text { Antrian } \\
\text { (m) }\end{array}$} & \multirow[b]{2}{*}{$\begin{array}{c}\text { Rasio } \\
\text { Kendaraan } \\
\text { stop/smp }\end{array}$} & \multirow[b]{2}{*}{$\begin{array}{c}\text { Jumlah } \\
\text { Kendaraan } \\
\text { Terhenti } \\
\text { smp/jam }\end{array}$} & \multicolumn{4}{|c|}{ Tundaan } \\
\hline & & & & & & $\begin{array}{c}\text { Tundaan } \\
\text { lalu } \\
\text { lintas } \\
\text { rata-rata } \\
\text { det/smp }\end{array}$ & $\begin{array}{c}\text { Tundaan } \\
\text { geometrik } \\
\text { rata-rata } \\
\text { det/smp }\end{array}$ & $\begin{array}{c}\text { Tundaan } \\
\text { rata- } \\
\text { rata } \\
\text { det } / \text { smp } \\
D=\end{array}$ & $\begin{array}{c}\text { Tundaan } \\
\text { total } \\
\text { smp.det }\end{array}$ \\
\hline $\mathrm{U}$ & \multirow{2}{*}{24} & 0.83 & 104.61 & 0.949 & 684.69 & 21.48 & 3.92 & 25.40 & 18332.18 \\
\hline $\mathrm{S}$ & & 0.29 & 25.56 & 0.582 & 103.97 & 10.02 & 4.65 & 14.67 & 2620.83 \\
\hline $\mathrm{T}$ & \multirow{2}{*}{27} & 0.78 & 60.00 & 0.874 & 515.49 & 17.76 & 3.73 & 21.49 & 12681.52 \\
\hline B & & 0.69 & 65.79 & 0.747 & 499.49 & 13.06 & 3.14 & 16.20 & 10829.04 \\
\hline
\end{tabular}

(sumber: Hasil Analisis, 2020)

Perbaikan kinerja kondisi simpang dapat dilakukan dengan salah satunya mengatur kembali waktu sinyal dengan mencari waktu yang optimal. Dengan skenario pertama yaitu merubah waktu sinyal yaitu panjang waktu hijau untuk pendekat Utara dan Selatan yaitu dari 30 detik menjadi 24 detik selanjutnya pendekat Timur dan Barat dari 30 detik menjadi 27 detik sehingga menghasilkan penurunan panjang antrian total yaitu sebesar $8,13 \%$ dari kondisi eksisting ini menunjukkan adanya pengurangan antrian kendaraan di keseluruhan lengan simpang. Tundaan total atau waktu tambahan yang diperlukan untuk melalui suatu simpang mengalami penurunan sebesar 6903 detik dari kondisi eksisting sehingga kendaraan yang melewati simpang tersebut mampu mengefisiensikan waktunya sebesar 13,44\%.

Tabel 4. Kinerja Simpang Bersinyal Pertokoan Kondisi Perubahan Fase

\begin{tabular}{|c|c|c|c|c|c|c|c|c|c|}
\hline \multirow[b]{2}{*}{ Pendekat } & \multirow[b]{2}{*}{$\begin{array}{l}\text { Waktu } \\
\text { sinyal } \\
\text { (green } \\
\text { time) }\end{array}$} & \multirow[b]{2}{*}{ DS } & \multirow[b]{2}{*}{$\begin{array}{l}\text { Panjang } \\
\text { Antrian } \\
\text { (m) }\end{array}$} & \multirow[b]{2}{*}{$\begin{array}{c}\text { Rasio } \\
\text { Kendaraan } \\
\text { stop/smp }\end{array}$} & \multirow[b]{2}{*}{$\begin{array}{c}\text { Jumlah } \\
\text { Kendaraan } \\
\text { Terhenti } \\
\text { smp/jam }\end{array}$} & \multicolumn{4}{|c|}{ Tundaan } \\
\hline & & & & & & $\begin{array}{c}\text { Tundaan } \\
\text { lalu } \\
\text { lintas } \\
\text { rata-rata } \\
\text { det/smp }\end{array}$ & $\begin{array}{c}\text { Tundaan } \\
\text { geometrik } \\
\text { rata-rata } \\
\text { det/smp }\end{array}$ & $\begin{array}{c}\text { Tundaan } \\
\text { rata- } \\
\text { rata } \\
\text { det } / \text { smp } \\
D=\end{array}$ & $\begin{array}{c}\text { Tundaan } \\
\text { total } \\
\text { smp.det }\end{array}$ \\
\hline $\mathrm{U}$ & 36 & 0.84 & 161.70 & 0.944 & 521.88 & 50.65 & 3.91 & 54.56 & 30176.28 \\
\hline $\mathrm{S}$ & 14 & 0.81 & 53.05 & 1.089 & 171.51 & 66.52 & 4.00 & 70.52 & 11109.65 \\
\hline $\mathrm{T}$ & \multirow{2}{*}{55} & 0.84 & 116.57 & 0.886 & 522.62 & 39.06 & 3.76 & 42.82 & 25265.15 \\
\hline B & & 0.83 & 143.42 & 0.866 & 578.69 & 37.07 & 3.54 & 40.61 & 27148.11 \\
\hline
\end{tabular}

Fase $1(\mathrm{U})$

36 det

Fase 2(S)

14 det

Fase 3 (B-T)

55 det

Gambar 4. Pengaturan Sinyal Simpang Tiga Fase 
Kondisi simulasi yang digunakan pada alternatif kedua adalah melakukan perubahan sistem, yaitu dengan merubah fase dari sebelumnya yang dua fase menjadi tiga fase, yang mana fase pergerakan Utara dan Selatan dipisah menjadi masing dan dilakukan perubahan waktu sinyal. Kondisi fase pada pergerakan Barat dan Timur tetap menjadi satu kesatuan seperti kondisi eksisting tetapi waktu sinyalnya diperpanjang daripada kondisi saat awal. Dari hasil simulasi tersebut kita mendapatkan dampak perubahan kinerja simpang, kondisi ini menghasilkan nilai DS yang cukup besar dari setiap lengan simpang dengan rata-rata berkisar 0,80 dan menyebabkan panjang antrian menjadi bertambah signifikan jika dilihat total lengan pendekat Barat dan Timur sebesar 112 meter.

\section{Pembahasan}

Masalah yang paling penting dalam kondisi yang memperburuk kinerja simpang adalah ketidaksesuian kapasitas simpang dalam melayani arus lalu lintas yang datang, hipotesis ini didasarkan pengalaman penelitian terdahulu yang seringkali menyebutkan hal demikian. Dengan didasarkan data dan analisis yang dilakukan bahwa ada indikasi yang membenarkan hal tersebut, dilihat dari data kondisi eksisting bahwa lengan pendekat yang memiliki arus yang lebih besar menghasilkan kinerja simpang yang mengalami penurunan, sesuai dengan standar dari MKJI 97' yang menetapkan kondisi simpang dalam keadaan jenuh (saturated). Dalam penelitian ini ada temuan yang diperoleh ketika hasilnya dilakukan simulasi dengan beberapa alternatif yang digunakan yaitu dengan melakukan rekayasa perubahan waktu sinya dan perubahan jumlah fase. Penggunaan alternatif rekayasa perubahan diharapkan dapat berdampak pada perbaikan kinerja simpang bersinyal yang berlokasi di pertokoan kota Majene.

Pada Tabel 1 menunjukkan pergerakan dominan arus lalu lintas terjadi pada lengan Utara, Barat dan Timur, untuk pergerakan Barat dan Timur ini merupakan pergerakan arus lalu lintas utama di jalan mayor yaitu lintas jalan nasional trans Mamuju-Makassar, yang mana selalu ramai dilewati kendaraan dengan volume yang besar. Tabel 2 dari hasil perhitungan dan analisis menggunakan MKJI 97 diperoleh kapasitas 719 smp/jam untuk lengan Timur dan 822 smp/jam untuk lengan Barat, untuk nilai arus lalu lintasnya diperoleh $590 \mathrm{smp} / \mathrm{jam}$ untuk lengan Timur dan $669 \mathrm{smp} / \mathrm{jam}$ untuk lengan Barat pada jam puncak, kemudian dianalisis lebih lanjut didapatkan kinerja simpang dengan nilai DS 0,81 dan 0,82 pada lengan Barat dan Timur yang diatur dengan panjang waktu sinyal hijau sebesar 30 detik.

Berdasarkan hasil kondisi eksisting dilakukan dua alternatif yang dapat digunakan seperti merubah waktu sinyal dengan jumlah fase yang tetap dan menambah jumlah fase serta merubah waktu sinyalnya. Pada Tabel 3 dengan kondisi simulasi merubah waktu sinyal untuk kedua fase, yaitu fase pertama dengan waktu 24 detik untuk pergerakan Utara ke Selatan ataupun sebaliknya dan fase kedua dengan waktu 27 detik pada pergerakan Timur ke Barat maupun sebaliknya. Hasil yang diperoleh dengan kondisi tersebut memperlihatkan terjadi perubahan nilai DS pada pergerakan arah Timur dan Barat yang mengalami penurunan, sedangkan pada pergerakan arah utara berubah nilainya menjadi naik dari sebelumnya 0,76 (Utara) dan 0,27 (Selatan) menjadi 0,83 (Utara) dan 0,29 (Selatan). Pada nilai antrian mengalami penurunan ke kondisi yang lebih baik yaitu 278,62 meter menjadi 255,96 meter serta tundaan rata simpang dari 89,35 det/smp menjadi 77,76 det/smp. Hasil tersebut memperlihatkan adanya peningkatan kinerja yang lebih baik dibandingkan dengan kondisi eksisting.

Hasil selanjutnya adalah kondisi alternatif kedua yaitu menambah jumlah fase dan merubah waktu sinyal, dimana hasil rekayasa alternatifnya tertulis pada Tabel 4 menunjukkan bahwa nilai DS-nya menjadi lebih meningkat daripada kondisi eksisting, hal ini terjadi karena perubahan jumlah fase dari dua menjadi tiga akan menimbulkan waktu tunggu kendaraan menjadi lebih panjang dalam satu siklus dan menyebabkan kinerjanya menurun. Nilai antrian mengalami perubahan dari 278,62 meter pada kondisi eksisting menjadi 474,74 meter pada kondisi alternatif perubahan fase dan waktu hijau.

\section{Kesimpulan}

Kinerja simpang bersinyal dapat ditandai dengan melihat nilai DS (degree of saturation) dari analisis yang dilakukan ataupun dengan cara melihat kondisi dilapangan dengan melihat antrian dan tundaan yang terjadi di simpang tersebut. Standar tingkat kemacetan simpang yang disarankan yaitu nilai DS $>0,85$ dengan level tingkat pelayanan (Level of Service) di kategori D dan E. Dari hasil pengumpulan data dan analisis kondisi eksisting yang dilakukan ditemukan bahwa kondisi kinerja simpang masuk dalam kategori mendekati nilai jenuh sesuai dengan standar yang ditetapkan oleh MKJI 97. Kondisi eksisting hasil analisis kinerja simpang bersinyal pertokoan memperlihatkan kondisi yang mendekati nilai jenuh, berdasarkan hasil tersebut diperlukan penanganan lebih lanjut untuk mencegah timbulnya kemacetan yang lebih parah. Berdasarkan hasil tersebut dilakukan alternatif-alternatif yang dapat dilakukan untuk tindakan preventif, alternatif yang dicoba tidak memungkingkan untuk melakukan perubahan geometrik simpang maupun merubah simpang bersinyal menjadi tidak bersinyal. Hasil analisis penanganan yang dapat dilakukan dengan cepat yaitu merubah waktu sinyal agar kinerja yang terjadi saat ini (eksisting) menjadi lebih baik yang tujuannya meningkatkan pelayanan dan mengantisipasi kemacetan di simpang tersebut. Saran yang perlu dilakukan adalah salah satunya perlu memperhatikan adanya tugu 
pahlawan yang tepat berada di simpang yang menjadikan pergerakan di simpang menjadi terganggu serta pada penelitian selanjutnya dapat dianalisis dengan memperhatikan kinerja simpang dari sisi kecepatan kendaraan dan analisis simpang yang menggunakan bundaran (roundabout) atau berdasarkan aturan Pedoman Kapasitas Jalan Indonesia (PKJI 2014).

\section{Referensi}

Badan Pusat Statistik Kab. Majene., (2019). Kabupaten Majene Dalam Angka 2019, Katalog: 1101002.7601, Kabupaten Majene.

Badan Pusat Statistik Kab. Majene., (2020). Kabupaten Majene Dalam Angka 2020, Katalog: 1102001.7601, Kabupaten Majene.

Direktorat Jenderal Bina Marga. (1997). BAB 2 Simpang Bersinyal. Bernaldy Ir. Manual Kapasitas Jalan Indonesia. Jakarta: Kementerian Pekerjaan Umum.

Haryanto, W. N., Fipiana, I. W., \& Pramonohadi, A. (xxxx). Kajian Kinerja Simpang Tak Bersinyal Jalan Inspeksi Saluran Kalimalang-Jalan Cipinang Indah Raya II Jakarta Timur, 103-116.

Kementerian Pekerjaan Umum. (2014). Pedoman Kapasitas Jalan Indonesia, Jakarta : KemenPU.

Khisty Jotin C., \& Lall Kent, B. (2005). Dasar-Dasar Rekayasa Transportasi Jilid 3. Jakarta: Erlangga.

Suhartono, Tjokrorahardjo, C., Setiawan, R., (xxxx). Simulasi Manajemen Lalu Lintas Untuk Meningkatan Kinerja Jaringan Jalan Raya Jemursari dan Jalan Margorejo Indah, Universitas Kristen Petra. 